Article

\title{
Sikh Self-Sacrifice and Religious Representation during World War I
}

\author{
John Soboslai \\ Department of Religion, Montclair State University, 1 Normal Ave., Montclair, NJ 07043, USA; \\ jsoboslai@gmail.com
}

Received: 5 January 2018; Accepted: 8 February 2018; Published: 10 February 2018

\begin{abstract}
This paper analyzes the ways Sikh constructions of sacrifice were created and employed to engender social change in the early twentieth century. Through an examination of letters written by Sikh soldiers serving in the British Indian Army during World War I and contemporary documents from within their global religious, legislative, and economic context, I argue that Sikhs mobilized conceptions of self-sacrifice in two distinct directions, both aiming at procuring greater political recognition and representation. Sikhs living outside the Indian subcontinent encouraged their fellows to rise up and throw off their colonial oppressors by recalling mythic moments of the past and highlighting the plight of colonial subjects of the British Raj. Receiving less discussion are Punjabi Sikhs who fought in British forces during the Great War and who spoke of their potential sacrifice as divinely sanctioned in service to a benevolent state. Both sides utilized religious symbolism in the hope that Sikhs would again enjoy a level of self-rule that had been lost with the arrival of the British Empire.
\end{abstract}

Keywords: Sikhism; World War I; self-sacrifice; imperialism; British Raj

When the British Raj gave way to the dual nation-states of India and Pakistan in 1947, the partitioning of the two was determined largely on the basis of religion. Pakistan became the home for the area's large Muslim population, and India for its Hindus. The British Government commissioned Cyril Radcliffe to draw the new borders with input from Jawaharal Nehru and Muhammad Ali Jinnah, and the 1941 Census of India provided the statistical basis for his determinations. Some provinces were easily assigned to one country or the other on the basis of their religious demographics, often leading to significant migratory shifts, but others possessed a more complex body politic that belied any easy assignment. Jammu and Kashmir, for example, still exist in a liminal state between the two countries, with claims of sovereignty being variously supported and contested by the populace.

One other such province was the diverse Punjab region, whose population included Hindus, Muslims, and a significant segment of Sikhs. While not a majority, the Sikhs' significant rural and urban populations combined with the presence of their sacred city of Amritsar gave them a special stake in the area's fate (Hill et al. 2008; Krishan 2004). The Punjab had also been the site of the last Sikh Empire, which had seen Sikh blood shed in its creation, maintenance, and defense until it was conquered by British forces only a century prior. This visceral connection to the land helped cultivate a desire for Sikhs to have control over their own destiny, something that would only be possible through the kinds of willing sacrifice that had characterized the great Sikhs of the past.

Here, it appears the global Sikh community split between those who felt violent revolution alone could lead to independence from colonial rule and those who believed autonomy would be the reward for devout service to the Empire. These two views could be broadly (and imprecisely) ascribed respectively to expatriates living abroad-especially in North America-and those still residing in the Land of the Five Rivers, the Punjab. The voices of the former would ultimately win the day, but that 
victory was largely the result of the latter's dashed hopes regarding what the sacrifice of Sikh soldiers in service to the Crown should merit.

This disappointment was the consequence of the broken promises of a government that was held in high esteem by many of its subjects. Letters written by Sikh soldiers during the First World War show a deep commitment to the Crown and a construction of self-sacrifice in battle as a political and religious duty. The rhetoric used by soldiers paints a picture of devotion for a sanctified imperial power. ${ }^{1}$ This would sharply contrast with experiences of Sikhs abroad, who were coming face-to-face with the brutality of life as imperial subjects. In what follows, both sides of this crucial debate will be examined and contextualized through contemporary materials preserved at the British Library's Indian Office Records, which provide insight into the rhetorical and symbolic means by which each side formulated their position. First situating the global Sikh community in their economic and socio-cultural environment at the dawn of the twentieth century, I will proceed by using letters written by Sikh sepoys (the designation of Indian soldiers serving under the British colonial government) alongside government documents and contemporary news sources to illuminate how World War I served as the crucible wherein the contours of Sikhism were being worked out through mobilizations for self-governance.

\section{Situating Sikhs on the Cusp of War}

On the eve of World War I, the Times of London told its readers that "As enlisted in our Indian army, the Sikhs were neither a race nor a sect. Nor, although they were Hindus by origin, could they be described as a caste" (Times History of the War 1914, IOR/Mss Eur/F170/8). The Times' dismissal of Sikhs as a religious sect was less a consequence of ignorance about the spiritual teachings that united Sikhs and more demonstrative of the uncertainty as to whether Sikhs constituted a discrete religious group separate from Hindus. The boundaries of "Hinduism" were still being drawn, and guru traditions had long and widely been accepted under its purview. Though Sikhism's founder, Guru Nanak, is recorded as unequivocally stating "We are neither Hindus nor Muslims" (Adi Granth, p. 1136), no such simple clarity existed for the communities under the British Raj.

Moreover, the distinction was a blurry one for Sikhs themselves; not only was the conception of a "religion" in the modern, Western sense out of keeping with traditional spiritual understandings of the Indian subcontinent, but the model of a discrete set of practices that fundamentally distinguished one group from another did not flush with existing indigenous knowledges. As Harjot Oberoi aptly puts it, "the either/or dichotomy is not to be taken for granted, for the religious life of the people, particularly in the pre-colonial period, was characterized by a continuum. There was much interpenetration and overlapping of communal identities" (Oberoi 1994, p. 12). It was only through a series of implicit and explicit negotiations in conversation with colonial expectations that led to the Sikhs being perceived as a distinct group severed from their Hindu brethren.

1 The materials used for this study were available through the British Library's India Office Records, to whom the author owes a debt of thanks. Letters were recorded as part of the program of censorship the British embarked upon to root out detractors during World War I, particularly in the subcontinent. They are available in English, translated by the censors, which could result in mislabeling of indigenous ideas or a lack of nuance in the communication due to a lack of understanding or orientalist ideas. The censors appear to have taken care in their translations, often noting where a word is not easily translatable into English and offering context for its meaning, but the concern stands. Also, there are clear indications that soldiers knew, at least by 1916, that their mail was being read, which could very well have influenced their writers to speak kindly about their superiors and government. Certainly granted, though some authors acknowledged openly that their mail was being censored while continuing to talk about the best way to get around censors to send everything from hair products to illicit drugs (see VanKoski 1995, pp. 47-50 for another perspective on these methodological issues). Frankness does not seem stymied by the colonial gaze. Moreover, the tone of many if not most of the missives come across not as cautiously sycophantic but nearly devotional. The content of most letters concerned events at home and descriptions of the hellish war in which they took part, and such could be accomplished (as many did) with no mention of the state for whom they fought. Instead, I think we see a common response during wartime: the state for which one risks their life is seen in the best terms to reaffirm for writer and reader the worthiness of their sacrifice. And even if we grant each problematic enumerated above, we are still left with insight into the ways that devotion is constructed using religious symbols that can increase our awareness of the forms that religion's interaction with politics and violence can take. 
One conversation partner was the Arya Samaj, a Hindu group whose attempts to officially establish the boundaries of Hinduism and link it to Indic identity aimed to include Sikhs as part of their tapestry (see Singh 2016, p. 192); see also (Fox 1985, pp. 158-71). The Arya Samaj was an indigenous spiritual institution preaching monotheism and a universal morality, none of which conflicted with Sikh principles. Moreover, cultural Western expectations about the zero-sum nature of religious affiliation — which demand an individual claim a solitary religious identity-were absent in the culture. Much like the Greek and Roman religions during late antiquity, multiple spiritual pathways could be pursued simultaneously without the need to exclusively subscribe to one. The Arya Samaj and like groups sought to employ religion as a basis of more unified identities, necessitating the demarcation of boundaries within the shifting spiritual landscape. At the same time, missionary activity throughout South Asia by Christians further brought religious identity politics to the fore. ${ }^{2}$ Into this amalgam, Sikhs attempted to define their own identity and by thus establishing themselves gain political recognition and authority.

Sikhs were not univocal when it came to their relationship with Hindu rites. Some groups sought to "purify" Sikhism of its Hindu influences and return to an ideal of the founders. The Singh Sabha movement rose as the Sikh counterpoint to the Arya Samaj and aimed to consolidate Sikhs around a core complex of symbols based in a canon of sources to increase a common group identification (Singh 2015). One step in this direction was the Anand Marriage Act, passed by the British colonial government in 1909, recognizing the legitimacy of Sikh wedding rites alongside other accepted forms. Until then, Sikhs were required to employ Hindu rites of marriage, which groups like the Chief Khalsa Diwan saw as insulting to their religious sensibilities.

Efforts of this sort would focus increasingly on the administration of Gurdwaras. Since the British annexed the Punjab in the mid-nineteenth century, Gurdwaras were managed by mahants—curators who were appointed by the British-and accusations of corruption and mismanagement were rife. In 1905, Sikh representatives won a legal battle to have Hindu statues removed from the Golden Temple at Amritsar, which helped lay the groundwork for the founding of the influential Khalsa Diwan Society in 1907. After the World War I, Gurdwara administration would emerge as the central concern of those hoping to delineate a Sikh space within the British Empire, and the mahants would ultimately be removed from power in the 1920s (see Riat 2011; Sohi 2014). These endeavors ultimately served to help create the discrete Sikh community it claimed to protect.

Other Sikhs, however, seemed content to continue worshipping along traditional Hindu lines. The Sanatan Sikh tradition excavated by Oberoi had deep roots in the populace, and it comfortably blended Vedic iconography and praxis with an openness to diverse religious elements (Oberoi 1994). Some even recognized (and continue to recognize) an ongoing tradition of living Gurus, contradicting what would become an essential aspect of Sikhism - that the lineage of living Gurus ended with Guru Gobind Singh who bestowed guruship on the Adi Granth (thereafter known as the Guru Granth Sahib) and recognized the Khalsa (the body politic of Sikhs) as the carrier of authority. The complex and multivalent nature of Sikhism was evident in the challenges of the 1891 British census. Fox (1985) captures the complications thus:

2 Concerns around conversion echoed throughout the Sikh community. Accusations of Christians pilfering Sikhs and thereby reducing Sikh numbers were partly driven by concerns over representation, but more significantly by concerns of keeping the panth strong. During World War I, the Young Men's Christian Association donated envelopes for use by Indian soldiers, a charity mitigated by their name clearly embossed across the enveloped. Sikhs immediately raised concerns about sending such stationary home, fearing it would lead family and friends to believe they had been converted to Christianity. Stories of forced conversion were not unknown, and Sikh sepoys were determined to maintain their identity. The army responded promptly, destroying the extant envelopes and discontinuing the program until substitutionary stationary could be provided. 
In the 1891 census, for example, over a third of the people who referred to themselves as Sikhs claimed they belonged to the Hindu religion and were Sikh only by sect. Of these, the great majority were Sajdharis ("Hindu Nanakpanthi" or "Hindu Sikh"), but fifteen percent were Singhs (Hindu "Gobind Singhi"). Two-thirds of the Sikhs believed they constituted a separate religion, and among these, not only were there the expected Singhs but also there was a large Sajdhari minority, comprising nearly 40 percent of them. The Sikh population was almost evenly divided between Singhs and Sajdharis. Later censuses showed less of this variation, in part because the British stopped publishing data on sects and in part because Singh reformism led the former Sajdharis to report themselves either as Hindus or Singhs. (p. 112)

Bureaucratic necessity combined with sociological imprecision resulted in inaccuracies about the character and number of the self-identifying Sikh populace and simultaneously revealed significant ambiguities regarding the imported category of "religion". As political recognition began increasingly revolving around religious bases, such concerns took on growing importance.

Sikhs were nevertheless listed among the "martial races" that dominated the military discourse of the British Indian Army. That label was less concerned with specific socio-biological features and used more as a catch-all phrase to guide military recruitment (Cohen 1971). According to VanKoski (1995), "martial fitness was perceived as a finessed ferocity stemming largely from a culturally inspired devotion to the aggressive defense of home, family and community. This was then transformed into a ruthless offence against enemies" (p. 44). A history of resilience and militarism paired with a demonstrated ability to thrive in a harsh climate led to Sikhs being labelled as a martial race and on that basis sought after for recruitment. The characterization was also proudly appropriated by many Sikhs who felt it suitably recognized their military prowess, and who would highlight features of their religious culture that flushed with British expectations. The martial race discourse exerted an orientalist force on constructions of religious Sikhism and in turn served as a gendered force to further distance Sikhs from "effeminate" Hindus (Jakobsh 2003; Mandair 2005).

Soldier's letters written during World War I reflected concerns about maintaining coherence as a religious group-encouraging Sikhs to remain unified and maintain a level of isolation from neighboring religious groups, referred to as "the society of strangers" (IOR/MIL/826/2/f.46v)—along with a reappraisal of Sikh history along martial lines: "Reading the Sikh history I find that the Sikhs are a warlike people, who in order to protect and elevate their honour have shed their blood freely in the past, and are shedding it as freely now. In the future too, they will continue freely to shed their blood to support the honour of the British government" (IOR/MIL/825/8/f.104v). In recognition of this taxonomic complexity, Brian Axel uses the term "nation" as synonym for the kinds of concentration and shifting theory of peoplehood, race, caste operative at time, and the term panth for speaking of the collective determined by Sikh religion itself (Axel 2001, p. 5), which I will follow.

External and internal forces pressed for a consolidation and nominalization of Sikhism, and the lack of clarity around Sikhs' relationship with Hindus had huge consequences in the political realm. Simplistically put, if Sikhs were Hindus, they were adequately represented; if Sikhism was a discrete religion in its own right, then Sikh voices deserved greater inclusion in their own right. As Anne Murphy has recognized, Sikhs rode a knife's blade trying to gain political representation through a religious frame; political activity could be construed as rebellious and dealt with forcefully, while attempts were made to accommodate religious practices (Murphy 2013; see Murphy 2015 for a discussion on how a "religious" sphere was distinguished from a "political" one during the period). The focus on Gurdwaras during the first decades of the twentieth century served to create a corporate body of Sikhs around religious centers, helping create the new category whilst also challenging it (Murphy 2015, p. 58). 
These battles were spurred on by a concurrent effort in British circles, where the Empire was revamping its organizational matrix in the Commonwealth and seeking to reaffirm a core British identity that marked colonized people as other (Qureshi 2013). Amidst fears of a Punjabi national identity that could threaten the integrity of the Raj, the British looked to religion as a new basis of distinction replacing language and location, preventing widespread solidarity, and producing more isolated and therefore easily controlled groups. Sikhism thus became "a force and a stake in [the] anticolonial struggle" (Gill 2014, p. 25). In spite of these troubles, many Sikhs felt their best chance for a voice in their own governance lay in showing themselves worthy of the special consideration they deserved as a "model minority" (Qureshi 2013). Nowhere could that demonstration be more on display than in the willing self-sacrifice of Sikh soldiers, and the contemporary economic situation in the Punjab helped further propel Sikhs into the ranks of the British Indian Army.

As the twentieth century dawned, the Land of Five Rivers was growing crowded. The Punjab was among the most fertile and most intensely worked land of the subcontinent, and as the population grew, less land was available to those who relied upon it for their livelihood. At the same time, the expansion of the global economy and the capitalist need to expand into new economies brought about an economic shift in the region from family run, household production companies (a system Richard Fox calls "petty commodity producers"; (Fox 1985, pp. 35-43)), to an increasing reliance on debt bondage. The subsistence levels of petty commodity production eked out little profit and paled in comparison to the excesses brought on by consumerist forms embraced by the empire.

Compounding such difficulties was the passage of the Punjab Land Alienation Act of 1900, which caused a seminal shift in agricultural sources for traditional social systems. Aimed at slowing the sale of huge tracts of land from peasants to higher caste moneylenders, which the British feared could lead to revolt, the Act divided Punjabis into "agriculturalist" and "nonagriculturalist" tribes and regulated the exchange of land rights between the two. Some seeking to settle on new lands were thereby prevented from full ownership, encouraging greater labor mobility (see Juergensmeyer 1979, pp. 176-82). Promises of land grants to Punjabi subjects on the completion of honorable service lured many into the military, and documents show early plans for the awarding of German East African territory to Sikhs on account of their service, championed by Major R.C. Goodfellow (IOR/L/PJ/6/1457). The failure of the British to fulfill those promises would significantly contribute to the anti-imperial shift in Sikh sentiments.

Typical of so many colonial and neo-colonial situations, the British "sought an Indian subject who would consume as British" and was thereby more vulnerable to the pressures wielded by capitalist entities (Murphy 2015, p. 151). Punjabis at the turn of the twentieth century were a case study of such forces, leading to greater numbers seeking new lands in which to ply and expand their trade, as well as ways to make a living outside these traditional modes of life. The British Indian Army provided such an opportunity, offering a pathway through sacrifice to a better life either within India or without.

\section{Sikh Soldiery}

When the British Empire began marshalling its troops to combat the German threat in 1914, Sikhs composed a significant proportion of its forces. The perceived martial nature of the Sikh nation was a result of history and ideology on behalf of the British but served to direct Sikh self-identity as well-not only in terms of the cultural attributes that would come to symbolize the Sikh panth but in terms of the relationship between the nation and the Empire in whose army Sikhs would serve.

The Sikhs' relationship to the British Empire is traceable at least as far back as Ranjit Singh, the "Lion of the Punjab", who established a sovereign Sikh polity in the early nineteenth century. This was the first and only period of ostensible self-government by Sikhs, remembered as a shining moment of Sikh history. After Ranjit Singh died in 1839, his empire began to fracture with power struggles, and after an uneasy truce with the British East India Trading Company (EITC), who had taken over lands abutting the Punjab, the Sikh Khalsa army embarked on a failed invasion of British-controlled lands. 
The battles that ensued, today known as the First Anglo-Sikh War, resulted in the ceding of territory to the EITC and a blow to Sikh unity.

In 1849, the EITC vanquished Sikh forces and inaugurated British rule in the Punjab. This episode, which became known as the Second Anglo-Sikh War, resulted in the annexation of the Punjab and the end of Sikh self-rule. The ferocity of Sikh resistance linked with the burgeoning martial races theory led newspapers of the time to extol the victory as one of the EITC's great triumphs (Axel 2001, p. 40). Sikh military prowess induced a heavy recruiting effort by the EITC, looking to bring Sikhs into the military forces of the Empire. Those efforts paid off during the Indian Mutiny of 1857, when Sikh forces played a major role in quelling the uprising. Though some estimates suggest up to seventy thousand Sikhs rebelled at one point, the Mutiny was led largely by Muslim and high-caste Hindus, toward whom many Sikhs had longstanding grievances (Cohen 1969). The former were seen as responsible for the Mughal Empire that was responsible for the death of the Sikh tenth and final human Guru Gobind Singh, and the latter enjoyed the benefits of a social system that marginalized the largely lower caste Sikhs. The result was a swift end to the uprising and an enhanced British appreciation for the Sikh nation.

For Sikhs, it provided an early experience of election and approbation from those who would rule the Punjab in the coming decades. It also connected with the Sikh militant ethic that was championed by the dominant Singh strand of Sikhism and explicitly supported by the British colonial authorities; consequently, the amritdhari image of the Sikh boasting the five "Ks"-including the unshorn hair (kes) and the sword (kirpan) - became the dominant form of Sikh practice, almost to the invisibility of other forms (see Singh 2016; Axel 2001; Oberoi 1994). The military virtues that had offered the EITC such stiff resistance would be put to use by the British Indian Army, and Sikhs would serve in both international and domestic venues to advance British interests. Ironically, while the Singh form had its origins tied to the declaration that the "the Khalsa [the Sikh community] shall rule", a sentiment of Sikh sovereignty affirmed during daily rites, the methods of obtaining and defending that rule would serve instead their conquerors.

The pride felt by Sikhs on account of their soldiery engendered further British forays into lower caste recruitment, and increased focus on the militaristic nature of the panth. More and more Sikhs began to identify as a common group regardless of caste, decreasing discrimination along socio-racial lines, particularly in military regiments. At the same time, the years around WWI saw the Indianization program of the British Indian Army, which was concerned with making more high rank positions available to soldiers of Indian heritage. Up to that point, the highest rank afforded an Indian solder (with very few exceptions) was a Viceroy Commissioned Officer (VCO), with the superior rank of King's Commissioned Officer (KCO) available only to those who attended England's elite Sandhurst Royal Military College. Without such training, Indian soldiers hit a ceiling in advancement. In 1917, partly in response to increased pressure from the Government of India seeking compensation for Indian service, a few spaces began being reserved for Indian enrollment, and the first King's Commissioned Indian Officers (KCIOs) began serving during World War I. British officials saw this innovation as quid pro quo for Indian sacrifice in the ranks, and while many Indians appear to have perceived in it the first nods toward the granting of Indian independence, the move suggested a direct correlation between sacrifice and socio-political mobility. When P.S. Sivaswamy Aiyer tabled his resolution in the Indian government seeking one-quarter of all spaces at Sandhurst be reserved for Indian soldiers, Sikh voices clamored for preferential admission on account of the quantities of blood they had shed for the Crown (Cohen 1971, pp. 73-81). This same dynamic would characterize Sikh demands following the conclusion of hostilities.

Though the voice of the Singh Sabha dominated, the plurality of Sikh communities and perspectives prohibited consensus on any topic. That was certainly the case regarding the relationship with the British Empire and the potential for greater say in Sikh governance. The legend of Ranjit Singh's polity remained alive, inspiring some-particularly those living outside the Indian subcontinent-to believe that violently throwing off the colonial yoke was the only way to true 
autonomy. Groups like the Ghadar Party and the later Akali Dal held such a position and took symbolic and literal steps toward such goals. On the other side, a significant segment of the Sikh gentry was convinced that loyal service to the Empire was the best way of securing such ends. This group included the majority of soldiers enlisted in the British India Army during World War I, who blended sacrificial motifs into conceptions of a divinely-appointed government and a commitment both political and religious. In what follows, I will analyze the contours of both viewpoints, beginning with the latter.

\section{Loyal Sikhs and the Sacred Empire}

Death in service to those who had conquered and dissembled the Sikh empire was not seen to be against conscience, but rather an act of loyalty expected from those who enjoyed the benefits of colonial rule. Some Sikhs appear to have felt they incurred a debt by living under the protection of the British Empire, one that required their lives as payment. Moreover, dying in service to justice was a much-celebrated virtue in the Sikh tradition. A number of Gurus were martyred, including the revered Gobind Singh, and a willingness to lay down one's life in love and service to Sikhism was a central virtue in their narratives (Fenech 2006). The war was seen to provide a longed-for and divinely sanctioned opportunity for those wishing to demonstrate their quality ${ }^{3}$. As one Sikh sepoy wrote,

It is the finest thing in the world to die for [our] King. I believe that God will keep those men happy whose aim in life is to be brave and loyal. I must also remark that it is up to you to help us for this is the time of our lives. Such an opportunity will not occur again for a hundred years and succeeding generations will reap the benefits of your exertions. (IOR/MIL/826/8/f.72r)

A number of themes in this statement echo throughout the corpus of letters: a divine approval of the Empire, the place of bravery and loyalty in Sikh life, a willingness to risk life in demonstration of these qualities, and the expectation that such efforts will result in benefits in this world and the next.

The rhetoric that most often couched this expectation was the need to be "true to one's salt", a phrase that appears with great frequency in letters of Sikh soldiers who were reminded to "be ever mindful altogether to be true to the salt of our Government ... And [be] profoundly grateful that this opportunity has come to us of proving our loyalty to our Government, whose praise is beyond telling" (IOR/MIL/825/4/f.163v). Prior to the war, the ability to prove one's worth waited in abeyance, and when presented with the opportunity to actualize this potential, many leapt at the chance. It was not conceived of only a matter of pride but also of religious obligation, as in this soldier's words that resembled many of his comrades: "Do your King's work well and be faithful. It is the order of the Guru that one should be faithful to the person whose salt one eats, and this is the time for us to do all that is possible for the King" (IOR/MIL/826/6/f.60v). According to another sepoy, this determination to prove worthy of the dual religio-political demand removed any concerns about death:

3 One favorite story is that of the Cherished Five, five faithful Sikhs who responded to Guru Gobind Singh's call for sacrifice. The story has it that at a huge gathering of Sikhs, Gobind Singh called for five volunteers to offer their heads as a sacrifice to God. He assured them of "all the happiness that their hearts desire" and the enjoyment of the "eternal hereafter", but those presents cowered in fear. After the Guru challenged the depth of their sincerity, Daya Singh walked up to the platform, where he was taken behind a curtain and in a substitution that recalls the Israelite God's treatment of Isaac, the Guru told him to remain silent while slaughtering a goat. He returned to the crowd with a bloodstained sword, where four more brave souls accepted the challenge, and the process was repeated. By the end, it is said that the Sikhs had found their faith and bravery and were clamoring to be sacrificed, when the Guru revealed the ruse and the unharmed volunteers. Their willingness to give their lives at the Guru's command marked them as models of devotion, and they are still remembered as paradigms of piousness. 
I am not afraid either to live or die. This is all in God's hands. I have escaped hitherto from a rain of shells and bombs and I believe it will be the same in the future. If He has laid down that my work shall lie in the midst of such a blazing fire, I shall go on doing it with His help. There are two points to note in this. The first is that God has ordained my career and the second is that loyalty to the King compels me to serve him and to be true to my salt ... No one fears death. If a demand is made for a volunteer to go ahead a thousand offer. (IOR/MIL/827/4/f.13r)

Even accepting that such claims were surely fueled to some degree by bravado, the language was consistently employed to justify risks in battle. "Eating the salt" of the Raj incurred a debt that surpassed monetary value and could only be settled in death. It was therefore thought to be "fitting for anyone who has eaten the salt of the great Government to die" (IOR/MIL/825/3/f.53r).

The demand to be true to one's salt appears to have its origins at least in part in Sikh scripture, where the phrase was used in reference to what man owed God and the Guru. Soldiers, it appears, transferred the obligations to God to the obligations owed the King. The fifth Sikh Guru, Guru Arjan Dev, is recorded in the Guru Granth Sahib as berating a follower, saying "You fool, you have forgotten the Lord from your mind!/You eat His salt, and then you are untrue to Him; before your very eyes, you shall be torn apart" (1001). It is the responsibility of those who seek to serve God to be true to Him unto death, and that same expectation now permeated political duties. In the Bhai Gurdas Varan, a popular Sikh text written around the time of Guru Arjan Dev, Sikhs are reminded that "The number of the faithful ones/Having eaten the salt (of a person), man becoming servant fetches water and grinds the corn./Such a faithful, in the battlefield gets killed piece to piece for the master" (Bhai Gurdas Varan, 35.11.1-2). It is not only the relationship of humans to God that has salient allegories; rendering service to any who contributed to your improved circumstances was considered divinely compulsory.

The same text demands the true Sikh die in service to this goal: "Truth, the true Sikh, the true Guru,/This is he who is true to the salt of his master and dies fighting for him on the battlefield" (Bhai Gurdas Varan, 30.14.1). It is not a peripheral obligation, but rather one that was understood to comment on the core nature of individual Sikhs. These lines are echoed by a Sikh soldier writing home to tell his veteran father how "those British officers, Sirdars [Sikh leaders] and men who lost their lives in this battle have fulfilled their obligations. It is for such an occasion that each man, when he enlists, swears on the Granth to be faithful, and it is therefore incumbent on us to fulfill our obligations towards the government whose salt we eat. One's life is not for this world only" (IOR/MIL/827/5/f.58v). Only death on the battlefield completes the religio-political project of a good Sikh subject, and its basis in religious literature gave self-sacrifice in war a ritualistic character. Sikh soldiers connected their duty to the Emperor with their duty to the divine, further giving the British Empire a divine aura that commanded respect, loyalty, and devotion.

That sacred quality was outright pursued by British officials in a number of ways. While the army's Indianization led to more Punjabi officers cultivating religious sentiments, British officers themselves attended religious celebrations. Sikh sepoys write proudly of English officers celebrating religious holidays and speaking of the panth with pride. These moments provided further opportunities to imbue military service to the empire with religious fervor. One soldier recounted one such evening:

The Sikh officers and soldiers of the 4th Cavalry held a religious meeting on the 16th July, lasting four hours ... At first Dr. Mosl Chand Sharma of the 4th Cavalry delivered a lecture on religion. The audience was very pleased with his lecture. He was followed by Lance Aaih Bota Singh of the 47th Sikhs who spoke on the grandeur and nobility of the Sikh religion. In the course of his lecture he also emphasized that in accordance with the orders of their Guru it was the duty of the Sikhs to serve their government loyally and faithfully, that they would never get such a rare opportunity to do so as the present one. All the people assembled received this statement with great enthusiasm. Captain Hills who was present at the meeting remarked that the Sikhs were great loyal soldiers of Government 
and constituted their right hand. Then a special prayer was made for the victory of our Government in the present war. (IOR/Mss Eur/F143/75.8)

Intentionally blending religious sentiment with duty to the Empire effectively bestowed sacrality on the goals of the British government. The government further nurtured such a connection through the abovementioned religious oath on the Guru Granth Sahib that accompanied the induction of Sikhs (Cohen 1971, p. 53). An amritdhari style baptism was often part of the initiation into the army as well, which is particularly interesting as it provided government support of the Singh brand of Sikhism, thereby compelling Sikhs to accept a theological stance as they sought to change their social situation.

Furthermore, many soldiers wrote of the empire itself in sacred terms. Often, it was framed as a government promised by the Guru: "The Guru has said the King should rule" (IOR/MIL/827/3/f.52r); "May the Guru ever keep over our heads the shadow of this great King" (IOR/MIL/827/2/f.48v), and "we hope that shadow will remain over us till the end of time" (IOR/MIL/826/4/f.66v). This sentiment seems to have roots in a prophecy of the ninth Sikh Guru Tegh Bahadur. One soldier writing to a newspaper at the time recalls the prophecy and its coloring of imperial service as religious obligation:

You will remember that British rule was foretold by our true leader Tegh Bahadur, the ninth Guru. It was established in India only for the protection and help of us Sikhs. It was on the voice of the Guru that the Eternal sent the English here. The blessings which this rule has brought to India are not concealed from you. The rise of Sikhs is due solely to this power. But for this, the poor Sikhs would have brought their unhappy existence to an end in some crows' [sic] pond ... This war for the Sikhs is a religious war, because the war is directed against that which our Guru established. (IOR/MIL/826/2/f.59r)

The reference nods to an apocryphal story circulated in Joseph Cunningham's influential 1918 work $A$ History of the Sikhs. It tells of the Guru gazing westward from the rooftop where he was imprisoned by the Mughal ruler Aurangzeb-a man hated for causing the deaths of a huge number of Sikhs, including the Guru himself-and predicting from that direction a force would come to level the Mughal Empire. Though the belief that the prophecy was meant to establish European authority over Sikhs was certainly contested, it was also fairly widespread as evidenced by the sepoy's letter.

Sikh soldiers went beyond prophecy to link political authority with religious sentiment. King George V was spoken with reverence as a pseudo-divinity himself. Multiple letters encouraged those at home to perform religious devotions to the image of the King in accordance with traditional spiritual practices- "This is the portrait of our gracious King. Keep it carefully and burn incense before it" (IOR/MIL/827/3/f.22r). ${ }^{4}$ One urged his family to "Worship [the portrait] every morning when you get up. This is an act of religious merit" (IOR/MIL/827/1/f.68v). By symbolically conflating the religious and political, the Empire was given authority over life to a greater extent than otherwise possible. Susan VanKoski (1995) notes that Sikhs spoke of this duty in ways that "set it apart from more earthly loyalties" (45), using language that highlights the set-apartness that characterizes conceptions of the sacred. For some, being true to one's salt was nothing more than even exchange; for others, service to the King and Emperor transcended life itself.

This sentiment is further evidenced by the this-worldly and next-worldly rewards for leal service:

We ought to give our lives for our Government. My brother, now is the opportunity for us to show our loyalty and we shall surely take it ... If we fight and live, the kind government will give us a title, Raja or Bahadur. If we fight and die, we shall go to 'surha' that is to say 'behisht' [heaven]..$^{5}$ I myself am ready for either course. For I am a son of Guru Gobind

4 This injunction itself serves as a demonstration of the broad acceptability of practices during the period. The use of incense in Sikh rituals was ultimately determined to be outside gurmat- the Guru's way—but Sikhs felt able to employ a diversity of traditional actions as part of their praxis.

5 Following this paragraph, the censor included a parenthetical notation: “'Surha' is the common Punjabi word for 'Heaven' which every Sikh would naturally use and know. The introduction of the explanatory term 'behisht', which has the same 
Singh. My very life I will sacrifice for my King. May the Guru sanctify the words which my tongue has spoken. (IOR/MIL/825/1/f.40v)

Numerous other letters directly connect death in the service to the Crown to earning paradise, such as one where a soldier consoled a family by assuring them "Your son is a hero, who has given his life for his King. He is not dead; he lives forever. He has gone straight to Paradise, because that is the reward of death in the field of battle in the service of the King. He has, in fact, achieved in an instant that which saints can only hope to secure after many years of trial" (IOR/MIL/827/5/f.70r-v). Soldiers falling in battle were martyrs, entitled to the same benefits, because the cause of the Sikhs was the cause of the Empire. Such beliefs not only would have provided solace to families of fallen sepoys, but also could account for some of the vigor with which Sikhs enrolled in the British Army ranks.

The obverse was also evident. Those who denied the sanctity of the Crown and withheld their help—or worse, acted in opposition to the Empire—injured Sikhs everywhere. Writing to one apparent recalcitrant, one soldier warned "Now look you, my brother, our father the King-Emperor of India needs us and any of us who refuses to help him in his need should be counted among the most polluted sinners" (IOR/MIL/825/1/f.156v; see also IOR/MIL/825/4/f.174r, which uses the same language). Though the language of sin may be a consequence of the censor's religious lexis, the Sikh's condemnation is indisputable. Others likewise affirmed that "our Guru has said that we must be faithful to the authority set over us and that if we fail to be so, we shall meet with his condemnation when we die" (IOR/MIL/827/4/f.74v). Self-sacrificing service in the Indian Army would assure a glorious postmortem existence; refusal would be stridently rebuked.

Such devotional assurances were supported by and lent support to the perception of the Crown as an agent of good and righteousness. While diaspora Sikhs across the sea grew increasingly frustrated with their colonizers, many Sikh in the military saw the actions of the Raj vis-à-vis their subjects as evidence of inspired morality. "Our Emperor is the most righteous Divine-king. No emperor is comparable to him ... The soldiers did their duty to the state with the intensest [sic] religious fervor" (IOR/Mss Eur/F143/75/S-33). Another soldier avowed "our King is admitted by all to be a just and wise and gracious Sovereign, one who respects the religion of each of his subject races, and all his subjects live in contentment under his rule. May God always maintain his sovereignty over the world and give his victory" (IOR/MIL/827/4/f.22r). Some even saw an altruism evident in Britain's entry into the Great War: "It is my firm faith that our King Emperor will be victorious in this war because His Majesty did not enter it from any personal motive but in order to save a weak kingdom" (IOR/Mss Eur/F143/75/S-33). For these Sikhs, the British government was not an oppressive power but a virtuous force they had the good fortune of serving. ${ }^{6}$

While such direct connections between Sikh doctrine and political service were by no means hegemonic, it is clear it was more than a minority perspective. It is no wonder that, in 1909, Max Arthur McAuliffe could write in his influential The Sikh Religion: Its Gurus, Sacred Writings and Author that "the orthodoxy of a Sikh means loyalty to his sovereign" (quoted in (Fox 1985, p. 159)). The King's quasi-divine stature assured Sikhs that they were on the side of good and that the promises made by imperial representatives for their service would be upheld.

In an oft-quoted line from the Adi Granth, Guru Nanak advises "Should thou be eager to join the game of love,/Enter my street with thy head placed in thy palm:/On stepping on to this path,/Sacrifice thy head without demur" (1412). If the fallen soldiers of World War I died playing the "game of love",

meaning, but is a loan word [apparently from the Hindi], suggests the idea that the letter may have been composed for the edification of the censor."

6 There is a question as to which came first: was it the perceived righteousness of the Empire and its goals that inspired a willingness of Sikhs to sacrifice their lives or was it their renown as warriors that led them to enlist, and then reinterpret their colonizers as divinely sanctioned to legitimize their sacrifice. Likely, it was a bit of both, but I would argue that amidst the censor's selection and the hermeneutic driven by hopes of dying for a worthy cause was an authentic appreciation for the Empire. 
their affection had been cultivated in direct and indirect ways, leading to a willingness to sacrifice for a political edifice that had at best a mixed history with the panth. But if soldiers who had laid their lives on the line for a divinely ordained government hoped their love would result in a beneficial existence under the Crown, Sikhs who had traveled abroad prior to the war's outbreak were jilted lovers, whose fury hell had nothing comparable.

\section{The Dissatisfied and Disillusioned Diaspora}

Sikhs had been emigrating from the Punjab and its environs for years before the Great War, often sending remittances home to support families still in the Raj. While Sikhs showed an ability to adapt to new social and economic systems, they proved resilient in terms of assimilation. Religious practices, cultural traditions, and other markers of identity were not relinquished lightly, stirring up concerns among other colonial populations in the British Empire. One place those concerns were most visible was in Canada, whose populace grew increasingly concerned with the growing number of Indian workers flooding into the agricultural economy. Spurred on by the deteriorating situation in the Punjab, the "Hindu Invasion" terrified farmers who felt their way of life threatened by the scores of Asians arriving on their shores and taking up work in agriculture, logging, and railroad construction. ("Hindu" was the label applied to all people from the Indian subcontinent and appears to have been willingly donned by Sikhs, further demonstrating the ambiguous identities at issue. See (Roy 2016)). While Sikh subjects of the Raj felt their status as British subjects entitled them to freedom of movement anywhere within the British domain, Canadian subjects sought methods of preventing an influx of peoples they saw as inferior and dangerous, and images of dark-skinned, turbaned workers were effectively put to use in nativist propaganda.

In response to these fears, the Canadian government passed the Immigration Act of 1910, creating another legal means of categorizing persons reminiscent of the Land Alienation Act of a decade earlier. The Immigration Act divided British subjects into Canadian citizens and "others"; the former had unqualified rights of admittance, while the latter were subject to a series of restrictions when seeking entrance into Canada. One such qualification demanded anyone immigrating from South Asia "come from the country of their birth, or citizenship, by a continuous journey and or through tickets purchased before leaving the country of their birth, or citizenship" (Continuous Journey Regulation of 1908). While security concerns were the given motive for this peculiar prerequisite-as is so common for ethnocentric and racist legislation-the rule served to nearly end immigration from the Indian subcontinent since no direct route existed for steamers. The act also required those arriving on Canadian shores have connections in the country already, along with heavy entry fees.

Anti-Asian sentiment among North Americans would be epitomized in the infamous Komagata Maru incident. In June of 1914, mere months before the British would enter World War I, a steamer bearing that name was held in the waters off Vancouver and refused entry into port on the authority of the Immigration Act. The ship had originated from Hong Kong, but nearly all of its passengers boarded in Shanghai, China, and Yokohama, Japan, which was a breach of the Continuous Passage regulation. The ship sat at Canadian berth for over two months, stranding nearly four hundred passengers from the Punjab just offshore. Obtaining supplies only took place after extensive negotiations, and both Canadian and British officials were keen to prevent the ship from docking, believing a large number of dangerous individuals_-particularly Sikhs_-were looking to stir up trouble in expatriate Indian communities.

Gurdit Singh, a Sikh, was responsible for organizing the doomed journey, either in hopes of supporting Sikh mobility abroad or looking to stir up anti-Imperial sentiment, or perhaps both. Although Parliamentarian J.D. Rees believed the passengers held the "avowed intention of promoting a revolutionary movement", which appears unlikely (see IOR/L/PJ/6/1325 File 2601 for this and other documents related to the Komagata Maru incident), such concerns seem mostly to stem from the negative perception of Gurdit Singh himself and contrasted with the self-perceptions of other Sikhs onboard. The "hypermobile Sikh subjectivities" that Anjali Gera Roy sees as a result of the 
routine transnational movement of Punjabi Sikhs during the last decades of the nineteenth century were confronted by a new distrust harbored in the minds of the imperial government (Roy 2016, p. 82). That distrust would ultimately lead to violence between those aboard the ship and military officials sent out, with conflicting reports of gunshots being fired from the ship. While no lives were lost while the steamer was held for nearly two months, tensions ran high on and off ship.

Worse yet, after the Komagata Maru was sent back to India, the passengers were to be held and possibly tried for their exploits while aboard the ship. After enduring months in poor conditions, passengers were forced to march long kilometers inland from the port to Calcutta, where their fates would be determined. According to records, one hundred and fifty Royal Fusiliers and thirty policemen were to escort the over two hundred Sikhs on the journey, but shortly after the expedition began, a British police sergeant sought to physically separate Gurdit Singh from the group. A scuffle broke out, and shots were fired, resulting in a full-scale riot in the area of Budge Budge that left twenty Sikhs dead and as many wounded.

British officials expressed sadness and surprise at such calamitous events, in part due to an expectation of willing submission from their colonized subjects. In general, it was determined that the passengers were corrupted by the insidious influence of Gurdit Singh, who was held responsible for the entire debacle. One official report held that "the Sikhs are, generally speaking, both courageous and excitable, and the passengers aboard the Komagata Maru were by this time in a state of acute discontent and irritation. Many of them were, we believe, full of the seditious doctrines which they had been taught on the journey, and had been led by Gurdit Singh to believe their ends could only be gained by force" (IOR/L/PJ/6/1338 File 5028). Note not only were the events put down to exasperation rather than desperation, but there was also an implicit sense that those Sikhs who sought their goals through force were foolish to not recognize the beneficence of the Empire towards its loyal subjects. This anonymous British official unknowingly echoed the two main strains of Sikh political thought at the time.

A number of voices clamored to be heard amidst the Komagata Maru and Budge Budge episodes, most notably the anti-colonial Ghadar party of North America. While Sikhs at large lamented this treatment of their countrymen (IOR/L/PJ/6/1394 File 3461 contains numerous report from public meetings of Sikhs across India expressing anger and demands for redress), the discourses seeking to influence Sikhs were here again divided: the Ghadar party and its compatriots sought to channel the anger stirred up at home and abroad into revolution, while others including some on the ship appear to have been unshaken in their loyalty.

The latter included some passengers held on the Komagata Maru who were careful not to vent their frustrations on the colonial authorities. Rather, they framed it as a misunderstanding that could be cleared up if only their devotion was made plain to the Canadian and English officials. One unnamed passenger spoke in passionate tones of the patriotism that unified Indian and Canadian subjects, and his words were printed in the popular Sun newspaper on 17 June 1914:

We are not angry at the Canadian authorities as [some] have been given to understand by immature consultations held under extreme difficulties with my fellow compatriots from the deck of our prison ship. We are sorry deep down in our hearts that burst with patriotism; we are sorry some of my compatriots, lashed by the disgrace brought about by an almost unbearable restraint, may have shown that anger that betokens the depth of feeling in strong men ... All we ask is to be treated as men and brothers. Let this false race prejudice be obliterated in a flood of real patriotism and we will stand shoulder to shoulder with you in making this Canada realize the consummation of which you dream. (IOR/L/PJ/6/1325 File 2601)

Unwavering in their allegiance, this passenger represented Sikhs who maintained a positive view of their rulers.

This was also the case at the Golden Temple in Amritsar, the heart of Sikhdom, where a meeting of Sikhs declared their continued loyalty to the Crown (Sohi 2014). At the Gurdwara in Calcutta, 
Sikh leaders declined to frame the Komagata Maru and Budge Budge incidents as evidence of widespread anticolonial attitudes but as "purely and simply an isolated local affair" of laborers who "misunderstood the beneficent intention of their Government" (Johnston 1979, p. 107; see too (Sohi 2014, p. 17)). Amar Singh, a member of the Lahore Gurdwara, "lamented the hardships of the Sikhs in Canada, and hoped that the British Government would not desert the community which had shed its blood in the Soudan [sic], South Africa and elsewhere on behalf of the British Raj, and had remained loyal throughout the days of the Mutiny [of 1857]" (IOR/L/PJ/6/1394 File 3461). Rather than use the events as an opportunity to condemn the Empire, some Sikhs felt it was an occasion to make clear their continued reliance on-and trust in - their colonizers.

However, the Komagata Maru episode and Budge Budge riot drove a further wedge between many Sikhs and the Crown on the eve of war. For these, the incidents would confirm that they were seen as inferior and disposable subjects, whose only hope in achieving equality would be a violent uprising (Sohi 2014; Juergensmeyer 1979). The Ghadar Party's founding documents stated frankly "the object of the organization has been fixed to free India from the British rulers" (quoted in (Muhay 2005, p. 23)). The Komagata Maru and Budge Budge disasters emboldened the Party and gave them broken Sikh bodies to rally around. Labelling those who perished at Budge Budge as martyrs, the Ghadar Party connected current events with Sikh martyrs of the past to create the appearance of an unbroken chain of violent rebellion against colonial forces, one which Sikhs were obliged to continue. Roy (2016) goes so far as to argue that the increased British surveillance of Sikhs following these concerning moments for the Empire completed the alienation of Sikhs, from which utter rebellion was ultimately assured. Letters written by Sikhs show the community was not at all univocal on such an issue. Instead, I would argue, the letters of Sikh soldiers show it was merely the foundation for the ultimate severing of good relations following the war.

World War I provided a golden opportunity for forces led by anger at these events to seek liberation from imperial rule. While the Empire was focused on events in Europe and North Africa, Ghadar agents would travel home to the Punjab and stir up the populace there with stories of harsh treatment and promises of equal representation under the law. In Oxnard, CA, a resolution was passed in 1914 declaring "the war has started in Europe. Let us throw the British government out of India. This is the most opportune time to indoctrinate the army-men and spread unrest among them in India" (quoted in (Muhay 2005, p. 35)). They declared war on the British, and over the next two years, thousands returned to the Indian subcontinent, smuggling in weapons and munitions and attempting to foment revolution.

Stories of those who stood firm with Guru Gobind Singh fighting for their freedom helped encourage Sikhs to take up arms against their imperial oppressors. The popular Ghadar newspaper published a poem to such effect in 1914:

For this Hind countless have sacrificed,/yet today we sit having forgotten these acts./The Tenth Guru lost his entire family,/Navi Ganni Shah could not bear the turmoil./The courageous Mati Das was torn in half with a saw,/while Taru Singh had his scalp severed for maintaining his hair [kes]./We are cowards whose birth has stained these heroes,/born of Bharat we have tarnished it too entirely. (quoted in (Gill 2014, p. 29))

Thanks to the global print network the Party had been able to establish, sending copies of their paper and this poem throughout North America and South Asia. Many took up this challenge to reaffirm their Sikhism on the basis of Gobind Singh's model, further bolstering the hegemony of the amritdhari brand and politically mobilizing Sikhs across the world. Over and again, the Ghadar Party's communications stressed that they continued the battle of Guru Gobind Singh, leading me to agree with Gill (2014) in his evaluation of the Ghadar Party's championing a new form of religiosity, as opposed to others who see them as a purely secular institution (Fox 1985; Juergensmeyer 1979).

Such symbolic connections made inroads into the Indian Army ranks as well, evidenced in the hundreds of sepoys who revolted against their British superior officers in the Singapore Mutiny of 
1915 (Roy 2016, p. 83). The disillusionment represented by the Ghadar Party and like groups is by no means absent from soldiers' letters. Complaints over their treatment both in the Army and at home in the Punjab were present, though to a lesser degree than the professions of loyalty and commitment delineated in the previous section. Still, the hardships of life ("The man whom God wished to punish is born in India" [IOR/MIL/825/5/f.5r]) and the belief that Sikhs ought not to serve the Empire in the War ("You ought to stay at home and defend your COUNTRY, and not go anywhere else" [IOR/MIL/825/4/f.115v, emphasis in original]) found voice in missives to and from the Punjab. There are also suggestions that the kinds of concerns raised about the rebellious streak of Sikhs found their way into the Indian Army administration. One letter notes that Sikhs who gathered together across regiments for religious services risked arrest (IOR/MIL/826/2/f.33r), and while there was little supporting evidence for such assertions, even rumors of the sort would serve to reinforce bonds between Sikhs as a discrete religious group to the detriment of British-Sikh relations. It also suggests that the esteem in which Sikh soldiers were held may not have been as ubiquitous as it seemed.

A number of letters also spoke directly to the disappointment Sikhs were increasingly feeling. The promises of the Raj were fading, and it was becoming evident to some soldiers that their willing sacrifice would not result in the kinds of benefits that helped inspire their devotion. The vigor and enthusiasm with which Sikhs had flocked to the Indian Army was flagging, with some suggesting it was initially done out of fear of authorities. One sepoy responded to such accusations by saying

\begin{abstract}
We are Sikhs, and the duty of Sikhs is to exalt in battle and show their prowess. When we were in India, except for God, we feared no one, and enlisted of our own free will. Now people say we enlisted from fear of the police; but we have no regard for Lumbardars [powerful local families] or police or anyone else. If we had anything to fear from the police, we should have soon settled accounts with them. Our object [in enlisting] was to obtain some benefit from the Sircar [government]. (IOR/MIL/827/2/f.22r)
\end{abstract}

Another soldier lamented at the treatment that went so counter to expectations, saying "No doubt [soldiering] is the work that Sikhs should do-were it only for our faith-but these people look on us as worse than dogs. What have we profited by it all?" (IOR/MIL/825/8/f.21r) Such voices appear to have been the minority in the ranks, but following the war, returning soldiers would increasingly take on this perspective. Their disillusionment would help push for Gurdwara administration reforms that would concern Sikhs for the several years that followed the war (Murphy 2015) and would ultimately lay the groundwork for the discontent that would crest in the decades around Indian independence.

While at the front, Sikhs learned of the institution of the Lucknow Pact of 1916, an act that while directed at Muslims would encourage the hopes of Sikhs for their own increased standing in government. Seeking to bring together ideologically diverse Indian Muslims and assure them fair representation, the Pact altered the way the lands of India were administered, increasing the presence and power of local authorities. It provided Muslim communities with half of the representative seats in recognition of their population size and in hopes of consolidating their community. The other half were ascribed to the Hindu population, dominated by the Arya Samaj, who refused to give Sikhs any such consideration, since, to them, Sikhism constituted nothing more than a strand of Hinduism (Singh 2015). In the midst of battle, Sikhs discovered their hopes of earning greater respect and autonomy through self-sacrifice may have been misplaced.

Still, many wrote to family and friends about their resilient hopes. Some spoke directly about their continued expectations of new lands (IOR/MIL/825/6/f.71r), others of their service as a seed for self-rule: "A seed cannot be killed. It will either die or will kill somebody, and if it lives it will gain sovereignty. It is the will of God" (IOR/MIL/825/1/f.180r). Some anticipated revisiting vengeance upon those at home who looked down enlisted men, looking forward to "return[ing] with joy to our native land. Then we will overthrow those at home who are now speaking ill of us. They will no doubt say in their hearts 'Alas, why were not these slain also?'” (IOR/MIL/825/8/f.19v) Though the Ghadar Party is not mentioned by name, the specter of undesirable elements certainly calls them to mind. One sepoy evoked the model of America for their hoped-for state (IOR/MIL/825/5/f.72r), and by 
and large, most appear to have held out hope for their own government to come through and thereby avoid the necessity of armed rebellion. Recognizing again the divine call to give their lives in service, one Sikh rejoiced "It is our very good fortune that our lives should be spent for the government. They are in the Guru's keeping. He must take them some time, but on the part of the government generosity and devotion to its subjects will remain" (IOR/MIL/826/1/f.64v). Devotion would be repaid with devotion, and one good turn would beget another.

\section{Aftermath}

The year after the war ended, such dreams seemed about to come true. Sikhs won a victory with the Montagu-Chelmsford Reforms, which officially established separate electorates for Sikhs and would be codified into law with the Government of India Act of 1919. Though this appeared to be the fruition of promises made, few were satisfied with the limited power bestowed as it seemed out of keeping with the level of service Sikhs provided during the War. Whatever resentment the Montagu-Chelmsford Reforms produced, however, it paled compared to another event in the same year that would deepen the divide over colonial rule in the Sikh community.

In April of 1919, Sikhs descended on Amritsar for the annual Baisakhi celebration heralding the new year. The holiday already carried a militaristic atmosphere, as it remembered the creation of the Khalsa under Guru Gobind Singh and his bestowal of sovereign authority onto the Sikh panth and the Adi Granth. It also provided an opportunity for Sikhs to assemble and give voice to grievances, which were legion six months after the close of World War I. Scores took the opportunity, and protests erupted in the town with Sikhs insisting the Empire's promises be fulfilled. Due in part to fears of even greater agitation around the recent arrest and deportation of leading Indian voices for independence - including Mohandas Gandhi and Dr. Saifuddin Kitchlew-the area around Amritsar was declared to be in a state of emergency by British officials. Sikhs arriving for the festival were likely unaware of the imposition of martial law, since the decision to extend the state of emergency by Colonel R.E.H. Dyer was not widely disseminated.

The crowd assembled in the Jallianwala Bagh, a public garden steps away from the Golden Temple, and when they did not swiftly disperse, they were fired upon by troops under Dyer's command. Low estimates have hundreds slaughtered by machine gun fire coming from soldiers that included the $54^{\text {th }}$ Sikh regiment, shaking the Sikh community and the Indian population at large. In a statement, Dyer would confess to continuing to fire after the crowd was dispersed in order to produce a "sufficient moral effect, from a military point of view, not only on those who were present but more specially throughout the Punjab" (quoted in (Wagner 2016)). His method was successful, though not entirely in the way he anticipated. Taking such harsh action against agitators for independence would serve to unite a number of disparate groups and add fuel to the movement for independence.

Bad enough was this massacring of Sikhs, but Aroor Singh, the manager of the Golden Temple, would offer Dyer a Siropa-a ceremonial robe of honor-and would make the Colonel an honorary Singh (though he was permitted to shave and continue smoking, thereby transgressing two central requirements of Singh Sikhs). Not only were Sikh soldiers deployed against members of the panth in the heart of the Sikh world, but the British-appointed manager of the holiest Sikh temple paid homage to the military official who was responsible for gunning down its congregants. In this moment, the discourse of sacrifice that had led to the heavy Sikh presence in the Indian Army finally fell apart. The military might of the colonizers, to which the Sikhs had long and vigorously added their potency, was now deployed against the very community that had supported it. It was a moment where their strands of militarism, service, sacrifice, and loyalty would all be reconfigured.

For the Sikh community, the massacre would tilt the scales of public sentiment away from the colonizers and invigorate the drive for Sikh autonomy. The year after the Jallianwala Bagh massacre, with calls for Indian independence on the rise, Sikhs renewed their efforts to obtain greater control of their own fate by seeking an enlarged role in the provincial government. Over and again, their sacrifices on the field of battle, their loyalty, and their egalitarian ethics were cited as reasons for 
special considerations. A Memorandum on Sikh Representation issued by an collective of Singh Sabhas to the Indian Statutory Commission in 1920 begins by noting how Sikhs "have suffered greatly in prestige and power, and even in the enjoyment of their rights", and that although "Sikhs have always regarded themselves as staunch allies of the British Government, and have always been acknowledged as such by the highest officers of the Crown ... not a single Sikh has been appointed to any high office of importance in the executive or judicial administration of the country" (IOR/Q/13/1/12 Item 12 E-Pun-174).

After delineating the rates at which Sikhs served during the war and the commendations Sikhs received (a much higher level than other Punjabi groups), the authors pressed upon their ideological alignment with the new era: "The Sikhs are a living and young community and they understand the principles of democracy and the art of administration. They also understand the principles of and have made and are ready to make sacrifices in discharging them. They are a race of men possessing strong potentialities which mark them out as a distinct from their countrymen of other religious persuasions" (Ibid.) Surely, the memo intimates, a divinely-appointed empire serving the good of humanity would recognize the worth of Sikh voices in support of a just government.

When Sikhs only received a portion of the representative seats to which they felt entitled, anger tore through the community. In a diplomatically worded note to the Secretary of State for India, Sikh leaders communicated their frustration:

Being encouraged that the British rule in India was established on the prophesy of our Ninth Guru, consequently the Sikhs have ever been loyal to the Government and shed their blood during the mutiny 1857-1858, in various frontier wars, in Sudan and the most bloody recent Great Wars in Europe, nay, in the whole world, they had sanguine hope that they being [a] fighting race, will be given over their due but on the scheme being out they were disappointed to find that they have not been given even their due even like Muhammadans and Hindus who have done very little during the wars unlike the Sikhs who have sacrificed their lives for the Government. (IOR/L/PJ/9/13 File 608/20)

From this point on, the Singhs seeking autonomy would replace loyalists Sikhs as the dominant relationship with the British (Fox 1985), and that shift would begin with the Gurdwara Reform movement headed by the Shiromani Gurdwara Parbandhak Committee. In the coming decades the Akali Dal, once a marginal group that the Raj sought to condemn and control, would see its ranks swell with Sikhs who were frustrated, disappointed, and armed. Consistently, in materials by such groups, the broken promises made to Sikh soldiers is used as the Q.E.D. of their argument that the British could not be trusted.

After the war, the British Empire experienced a literal fall from grace, and created a veteran community angered by their treatment and frustrated at their prospects. Similar to US soldiers returning from Vietnam, Sikh sepoys came home disillusioned with the government, but unlike US soldiers, they were actively sought out to participate in efforts to address the situation. Returning Sikh soldiers brought home from the Great War a powerful symbol of bravery, honor, and willingness to sacrifice that demanded respect throughout the Sikh world. Their participation, along with the absent-presence of those who had fallen on foreign battlefields, shifted the religio-political landscape of the global Sikh community in the years leading to World War II and ultimately independence.

The Sikh nation under the British Raj felt pressures from a number of sides. Economic uncertainty combined with legislative buffetings pressed Sikhs into securing greater control over their destinies, but the means of obtaining such ends diverged. Some, emboldened by the British approbation of Sikh martial prowess, flocked to the ranks of the British Indian Army, believing their sacrifice was an obligation to those whose salt they ate. They also felt assured that their efforts would be rewarded by a greater voice in their governance, in line with the explicit and implicit promises of the Raj. When those promises failed, ex-soldiers found themselves aligned with the anti-imperial sentiments that had brewed in those who sought a livelihood in other colonized lands. Having been shown by the 
Komagata Maru and Budge Budge disasters that the colonizers were not to be trusted, many Sikhs living outside the Punjab began formulating plans for revolution. While these never fully materialized, the Jallianwala Bagh massacre finally tipped the scales toward a broad anger toward the British. Such sentiments were exacerbated when the Radcliffe Line split the Punjab in twain, half in Pakistan and half in India, leaving Sikhs without the levels of self-rule they desired. Faced with this ultimate failure, the loyal Sikh soldier who served the Empire faithfully was all but effaced from Sikh memory. Such a conclusion was far from given at the beginning of the twentieth century when contrasting visions of the character, boundaries, and relationships of Sikhism sought to achieve their ends through the language and symbol of self-sacrifice.

Conflicts of Interest: The author declares no conflicts of interest.

\section{References}

Axel, Brian Keith. 2001. The Nation's Tortured Body: Violence, Representation, and the Formation of a Sikh Diaspora. Durham: Duke University Press.

Cohen, Stephen P. 1969. The Untouchable Soldier: Caste, Politics, and the Indian Army. The Journal of Asian Studies 28: 453-68. [CrossRef]

Cohen, Stephen P. 1971. The Indian Army: Its Contribution to the Development of a Nation. Berkeley: University of California Press.

Fenech, Louis. 2006. Martyrdom in the Sikh Tradition. New York: Oxford University Press.

Fox, Richard G. 1985. Lions of the Punjab: Culture in the Making. Berkeley: University of California Press.

Gill, Parmbir Singh. 2014. A Different Kind of Dissidence: The Ghadar Party, Sikh History and the Politics of Anticolonial Mobilization. Sikh Formations 10: 23-41. [CrossRef]

Hill, K., W. Selzer, J. Leaning, S. J. Malik, and S. S. Russell. 2008. The Demographic Impact of Partition in the Punjab in 1947. Population Studies 62: 155-70. [CrossRef] [PubMed]

Jakobsh, Doris C. 2003. Relocating Gender in Sikh History: Transformation, Meaning and Identity. New York: Oxford University Press.

Johnston, Hugh. 1979. The Voyage of the Komagata Maru: The Sikh Challenge to Canada's Colour Bar. New Delhi: Oxford University Press.

Juergensmeyer, Mark. 1979. The Ghadar Syndrome: Immigrant Sikhs and Nationalist Pride. In Sikh Studies: Comparative Perspectives on a Changing Tradition. Edited by Juergensmeyer, Mark and N. Gerald Barrier. Berkeley: Graduate Theological Union, pp. 173-90.

Krishan, Gopal. 2004. Demography of the Punjab (1849-1947). Journal of Punjab Studies 11: 77-89.

Mandair, Navdeep. 2005. (En)Gendered Sikhism: The Iconolatry of Manliness in the Making of Sikh Identity. Sikh Formations 1: 39-55. [CrossRef]

Muhay, Gurcharan Singh. 2005. A Zeal for Martyrdom: Kartar Singh Sarabha. Ludhiana: Lahore Book Shop.

Murphy, Anne. 2013. Defining the Religious and the Political: The administration of Sikh religious sites in colonial India and the making of a public sphere. Sikh Formations 9: 51-62. [CrossRef]

Murphy, Anne. 2015. The Formation of the Ethical Sikh Subject in the era of British Colonial Reform. Sikh Formations 11: 149-59. [CrossRef]

Oberoi, Harjot. 1994. The Construction of Religious Boundaries: Culture, Identity and Diversity in the Sikh Tradition. New York: Oxford University Press.

Qureshi, Kaveri. 2013. Diasporic Citizenship and Militarization: Punjabi Soldiers in the World Wars. Citizenship Studies 17: 400-13. [CrossRef]

Riat, Pritpal Kaur. 2011. A Historical and Theological Evaluation of the Sikh Gurdwaras Act, 1925. Ph.D. thesis, University of Birmingham, Birmingham, UK.

Roy, Anjali Gera. 2016. Making and Unmaking of Strangers-The Komagata Maru Episode and the Alienation of Sikhs as Undesirable Persons. Sikh Formations 12: 67-86. [CrossRef]

Singh, Kuldip. 2015. Sikh Ethnonationalism and Its Contested Articulation during Militancy in Punjab. Journal of Punjab Studies 22: 25-42.

Singh, Birinder Pal. 2016. Sikh Militants' Terms of Discourse: Religion, Khalistan/nation, and violence. Sikh Formations 12: 191-206. [CrossRef] 
Sohi, Seema. 2014. Sites of 'Sedition', Sites of Liberation: Gurdwaras, the Ghadar Party, and Anticolonial Mobilization. Sikh Formations 10: 5-22. [CrossRef]

VanKoski, Susan. 1995. Letters Home, 1915-1916: Punjabi Soldiers Reflect on War and Life in Europe and their Meanings for Home and Self. International Journal of Punjab Studies 2: 43-64.

Wagner, Kim A. 2016. 'Calculated to Strike Terror': The Amritsar Massacre and the Spectacle of Colonial Violence. Past and Present 233: 185-225. [CrossRef] 